\title{
Spatial Analysis of Accident Spots Using Weighted Severity Index (WSI) and Density-Based Clustering Algorithm
}

\author{
$*^{1}$ OLUSINA, JO; ${ }^{2}$ AJANAKU, WA \\ ${ }^{1}$ Department of Surveying \& Geoinformatics, Faculty of Engineering, University of Lagos, Lagos State, Nigeria; ${ }^{2 c} \%$ Department of \\ Surveying \& Geoinformatics, Faculty of Engineering, University of Lagos, Lagos State, Nigeria; wemimoajax01@yahoo.com \\ Corresponding Author: joolusinal@yahoo.com
}

\begin{abstract}
This study is based on evaluation of various factors that cause road accidents in Lagos Metropolis. Fourteen (14) factors/drivers were identified which tend to influence an occurrence of accident on Lagos roads. In order to study the pattern of accidents in the Metropolis, several different spatial and non-spatial datasets were collected, processed and analysed. Weighted Severity Index (WSI) was created based on these factors/drivers. Also, Density-based Clustering for Traffic Accident Risk (DBCTAR) was carried out to assist in ascertaining the distribution of Black Spots Severity (BSS). Results obtained include: shortestpath analysis, service area analysis, accident spot severity and vulnerability level across the Metropolis based on the Weighted Severity Index (WSI). The study reveals that, accidents are not always caused as a result of bad roads but by the smoothness of roads such as expressway with accident spots distance band of $300 \mathrm{~m}-500 \mathrm{~m}$ and $3.6 \%$ of the accidents is as a result of pedestrians avoiding the use of pedestrian bridges/aid even when they are available. (C) JASEM

https://dx.doi.org/10.4314/jasem.v21i2.22
\end{abstract}

Key Words: Accident Spots, Weighted Severity Index (WSI), Vulnerability, Pedestrians, Transportation.

A road accident refers to any accident involving at least one road vehicle, occurring on a road open to public circulation, and in which at least one person is injured or killed (National Institute of Statistics and Economic Studies, saved 2017). Road traffic injuries are a major cause of morbidity and mortality worldwide, but especially in low-and-middle income countries (Nkwonta, 2013). The World Health Organization (WHO) estimates that more than 3000 people are killed every day in road traffic crashes globally, with at least 30,000 others injured or disabled. This adds up to over 1 million people killed and between 20-50 million injured or crippled in road traffic crashes each year (WHO, 2013; Krug, Sharma and Lozano, 2000). Unfortunately, the popular means of transportation in Nigeria is the road transport.

Road accidents do not simply happen, they are caused (Sheriff, 2009). The causes of road traffic accidents are multi-factorial. These factors can be divided broadly into three (3) major factors, they literally include: Driver, Vehicle and Roadway factors. According to Eze (2013), accidents can be caused by a combination of these factors. $\mathrm{He}$ analysed that driver factors solely contribute to about $57 \%$ of road traffic accidents and 43\% either alone or in combination with other factors. Details on these factors can be found in Agbonkhese et al. (2013); Abiola (2011 and Atubi (2010).

Road accidents may be fatal, resulting in deaths of the road users (Passengers, Drivers or Pedestrians), or minor when it is not severe enough as to cause substantial hardship. The dividing line between minor and serious accident is however blurred (Sarin, 1998).

In Nigeria, there are several agencies saddled with the responsibility of traffic law enforcement, such as: The Nigeria Police Force (NPF)-Traffic Unit, Federal Road Safety Agency (FRSC), the Lagos State Traffic Management Authority (LASTMA), the Vehicle Inspection Officer (VIO), among several others. They all coordinate and enforce the protection of lives and property on Nigerian roads. Despite the law enforcement forces, the carnage on our roads still persists at a worrisome level (LASTMA, 2013). Lagos State Government disclosed that 13,398 road accidents, which included commercial motorcycle (called Okada), were recorded in the last 15 months. Out of these mishaps, 148 deaths were recorded (LASTMA, 2013).

Therefore, the use of technology has become a necessity. Geospatial Information Systems (GIS) as a tool can be used to map accident location/spot patterns, analyse accident data, evaluate accident data in relation to certain infrastructure parameter such as the number of accident spots in a built-up area or the numbers of accidents per period (e.g. per day) and black spots priority value criterion (Steenberghen et al., 2004; Geurts and Wets 2003).

This research is based on identifying accident spots and the pattern of its frequency at a spot (i.e. the 
Black spots) across Lagos Metropolis in order to provide adequate information to stakeholders. Spatial analysis of the distribution of these accident spots using Weighted Severity Index (WSI) was carried out. A Density-based Clustering Algorithm for Traffic Accident Risk (DBCTAR) was used to determine accident concentrations with severity levels in a Geospatial Information Systems (GIS) environment. This work is only limited to highways and expressways, and does not cover access roads and core engineering road design.

\section{MATERIALS AND METHODS}

Study Area: Lagos State (Figure 1.0) is situated in the South Western part of Nigeria. The State is divided into 20 Local Government Areas (LGA). Lagos Metropolitan Area incorporates sixteen (16) of its (20) LGAs and Ikeja serves as the Administrative Capital. The rate of population growth in Lagos Metropolis is about 600,000 per annum with an average density of over 20,000 persons $/ \mathrm{km}^{2}$ in the built-up area of the Metropolitan Lagos. Lagos, being the sixth largest city in the world with a population of over 17 million people and over 10 million commuters on its roads on a daily basis, registers over 200,000 vehicles annually and records of 224 vehicles per kilometre as against 15 vehicles per kilometre in other states (LASTMA, 2013).

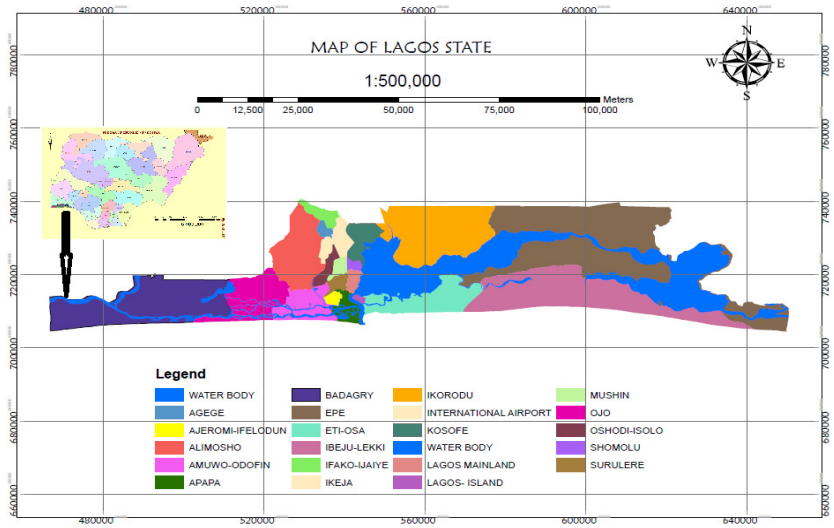

Fig. 1: Administrative Map of the Study Area- Lagos State (Lagos State Ministry of Physical Planning, 2014).

Accident Concentration Detection: Landles (1979) stated that among the available methods in accident studies, Black Spots (BS) are often regarded as an effective way to identify high-risk road accident sites or areas. Once the accident sites can be positioned on a map, certain criteria could be adopted, for instance, a black spot may be defined as the amount of spots vulnerable to accidents, the distance length of the spot, and so on.

The principles in using black spot method are based on the following assumptions: the site/area must have enough accidents to identify a pattern, the site/area must have enough accidents of the same type, and the accidents could be located on a map based platform. Once a black spot could be determined, the proposed engineering treatments could follow (Kanellaidis, 1999 and Tabatabaee and Johari, 2012).

Adequate identification of an agglomerated area in a road network is mostly simplified into an assignment that finds concentrations of point event in a network. Numbers of strategies have evolved, proposed and adopted, including spatial autocorrelation methods and kernel analysis methods. For its global acceptability and ease of computation, the Kernel analysis method was adopted in this work (Wang and Wang, 2011).

Kernel Density methods was used to calculate and produce a density surface from point features. Here, the density is the total number of accidents per unit area. Usually, the methods divide the whole area into grid cells, and calculate the density of point features around each output raster cell. To do the calculation, a hump or kernel with a mathematical equation, called a kernel function (Equation 1), was applied to each accident point [Hartigan 1975; Hartigan \& Wong 1979]

Methods: It entails data acquisition, data processing, database design, database creation, map generation, queries and analysis.

Data Acquisition- Reconnaissance was carried out and data acquisition was from two sources:

Primary Data: These include; geometric (coordinates) and attribute data of the Accident Spots, Ambulance points, Police station/posts, Hospital locations, etc. that are along major roads using Garmin handled Global Positioning System (GPS). Also, photographs of the accident spots and interviews with all stakeholders, such as e.g. police, road users, traffic 
officials, etc., were conducted to ascertain the black spots.

Secondary Data: These include; Google earth imagery, research materials, records of online accidents reports (e.g. WebPages, Blogs, Traffic Radio broadcast, etc.). All these assisted in easy accident location identification and speedy information gathering.

Data Processing- This involved all the processes undertaken ranging from data sorting and filtering; data format and conversions (maps digitization and saved as Tiff, Jpeg and Shp; Photographs saved as jpeg and png; GPS and Google Earth Coordinates transformation); database creation; queries; analysis and results generation using various software package such as; Microsoft Excel 2007, ArcMap 10.1 and Garmin MapSource.

\section{Modelling Road Accident Weight Severity:}

A kernel function as a weighting function to estimate variables' density ranging from 0 to 10 with a given radius, depending on its distance to the accident point. All the values from different points at a given cell were then totalled as the density estimation value.
The formula used to calculate the kernel density values at location $(x, y)$ is defined by:

$\mathrm{D}_{(x, y)}=\frac{1}{n r^{2}} \sum_{t=1}^{n} K\left(\frac{t_{t}}{x}\right)$

Where, $\mathrm{D}_{(\boldsymbol{x}, y)}=$ density estimation value at location $(x, y) ; n=$ is the number of observations; $r=$ is the smoothing parameter called bandwidth (is the search radius, only points within $r$ are used to estimate); $K=$ is the kernel function, it is the distance between the location $(x, y)$ and location of the $i$ th observation (Wang, 2012). The raster cells with high values indicate the accident concentration areas. (Steenberghen et al., 2004).

The Weighted Severity Index (WSI) method adopted was centered on a system of assigning scores based on the number and severity of accidents in a particular location in the last four years (2010-2014). The various identified fourteen (14) factors which tend to influence an occurrence of accident on Lagos roads, are assigned weights on a scale of $0-10$, such that that factor, which tends to increase the probability of the accidents is assigned lower weights [Table 1] (Vyas, Honnappanavar and Balakrishna, 2015).

Table 1: Factors used in the WSI determination, with possible Weights (adapted from Vyas, Honnappanavar and Balakrishna, 2015).

\begin{tabular}{|c|c|c|c|c|c|c|c|}
\hline$S / N$ & Factors & $\begin{array}{l}\text { Possible } \\
\text { Variation }\end{array}$ & $\begin{array}{l}\text { Weights } \\
\text { Assigned }\end{array}$ & $S / N$ & Factors & Possible Variation & $\begin{array}{l}\text { Weights } \\
\text { Assigned }\end{array}$ \\
\hline \multirow[b]{3}{*}{$\mathrm{F} 1$} & \multirow{3}{*}{$\begin{array}{l}\text { No. of Lanes in } \\
\text { each direction }\end{array}$} & 1 & 2 & \multirow[b]{3}{*}{ F8 } & \multirow[b]{3}{*}{ No. of Vehicle per day } & $<10000$ & 10 \\
\hline & & 2 & 6 & & & $10000-30000$ & 8 \\
\hline & & 4 & 10 & & & $30000->50000$ & 4 \\
\hline \multirow[b]{4}{*}{$\mathrm{F} 2$} & \multirow[b]{4}{*}{ Width of Road } & $6-8 m$ & 3 & \multirow[b]{3}{*}{ F9 } & \multirow[b]{3}{*}{ *Shoulders } & Paved & 10 \\
\hline & & $8-10 m$ & 5 & & & Unpaved & 6 \\
\hline & & $10-12 m$ & 7 & & & No & 0 \\
\hline & & $>12 \mathrm{~m}$ & 10 & \multirow[b]{2}{*}{ F10 } & Culvert/Median & Yes & 10 \\
\hline \multirow[b]{2}{*}{ F3 } & \multirow[b]{2}{*}{ Type of Road } & Access & 2 & & No/Temporary Barrier & No & 4 \\
\hline & & Express & 10 & \multirow[b]{4}{*}{ F11 } & \multirow{4}{*}{$\begin{array}{l}\text { *Traffic Control } \\
\text { Mechanism }\end{array}$} & Good & 10 \\
\hline \multirow[b]{2}{*}{$\mathrm{F} 4$} & \multirow[b]{2}{*}{ Surface Type } & Bitumen & 4 & & & Fair & 6 \\
\hline & & Concrete & 10 & & & insufficient & 4 \\
\hline \multirow[b]{3}{*}{ F5 } & \multirow{3}{*}{$\begin{array}{l}\text { Surface } \\
\text { Condition }\end{array}$} & Good & 10 & & & Not available & 0 \\
\hline & & Fair & 6 & \multirow[b]{4}{*}{$\mathrm{F} 12$} & \multirow{4}{*}{$\begin{array}{l}\text { *Pedestrian Aid } \\
\text { Movement Across the } \\
\text { Road }\end{array}$} & $\begin{array}{c}\text { Total ped-bridge } \\
\text { movement }\end{array}$ & 10 \\
\hline & & poor & 1 & & & Zebra line & 6 \\
\hline \multirow[b]{4}{*}{ F6 } & \multirow{4}{*}{$\begin{array}{l}\text { *Drainage } \\
\text { Facility } \\
\text { Condition }\end{array}$} & Good & 10 & & & Avoid Pedestrian Aid & 4 \\
\hline & & Satisfactory & 6 & & & Not available & 0 \\
\hline & & Poor & 2 & \multirow[b]{3}{*}{ F13 } & \multirow{3}{*}{$\begin{array}{l}\text { Freeness of Human } \\
\text { Activities at Shoulder }\end{array}$} & Total Clear & 10 \\
\hline & & Lack Availability & 0 & & & Fairly Clear & 4 \\
\hline \multirow{6}{*}{$\mathrm{F} 7$} & \multirow{6}{*}{ Vehicle Type } & Heavy & 10 & & & Congested & 2 \\
\hline & & Vehicles & 8 & \multirow[b]{5}{*}{ F14 } & \multirow[b]{5}{*}{ Road Design/ Shape } & Straight & 10 \\
\hline & & Bus/Trucks & 4 & & & Slope & 8 \\
\hline & & Cars & 2 & & & Sharp Bend & 6 \\
\hline & & Motorcycles & 1 & & & T-Intersection & 2 \\
\hline & & & & & & Cross -Intersection & 1 \\
\hline
\end{tabular}

The total weight for each road link was calculated and normalized using assigned maximum weight [140] (Eq. 2):

T.W. $=\left(\Sigma \mathrm{W}_{\mathrm{i}}\right) \times 100 / 140$

where: T.W. = Total weight; $W_{i}=\Sigma$ Individual Weight of Factors/road segment. 
This result was exported into ARCGIS 10.1 software (UTM WGS 1984, Zone 31 coordinate system), and thereafter the Weighted Severity Index (WSI) map was generated using the ArcMap Analysis tool. The classification of roads for accident occurrence was based on the total weights (Equation 2). Consequently, based on the various total weights per segment/spot, all the road links/segments or spots were classified into five Venerability Zones: Very High, High, Medium, Low and Very Low (Table 2).

Table 2: Prioritization for Weight Severity Index (WSI) Scheme.

\begin{tabular}{ccc}
\hline S/N & $\begin{array}{c}\text { Total Weight after } \\
\text { Normalization }\end{array}$ & $\begin{array}{c}\text { Accident Prone Classification/ } \\
\text { Vulnerability Level }\end{array}$ \\
\hline 1 & $>60$ & Very Low \\
2 & $50-60$ & Low \\
3 & $40-49$ & Medium \\
4 & $30-39$ & High \\
5 & $0-29$ & Very High \\
\hline
\end{tabular}

\section{RESULTS AND DISCUSSION}

With the spatial database designed and implementation, analytical task of query generation and spatial search were embarked upon, and the following results were obtained:

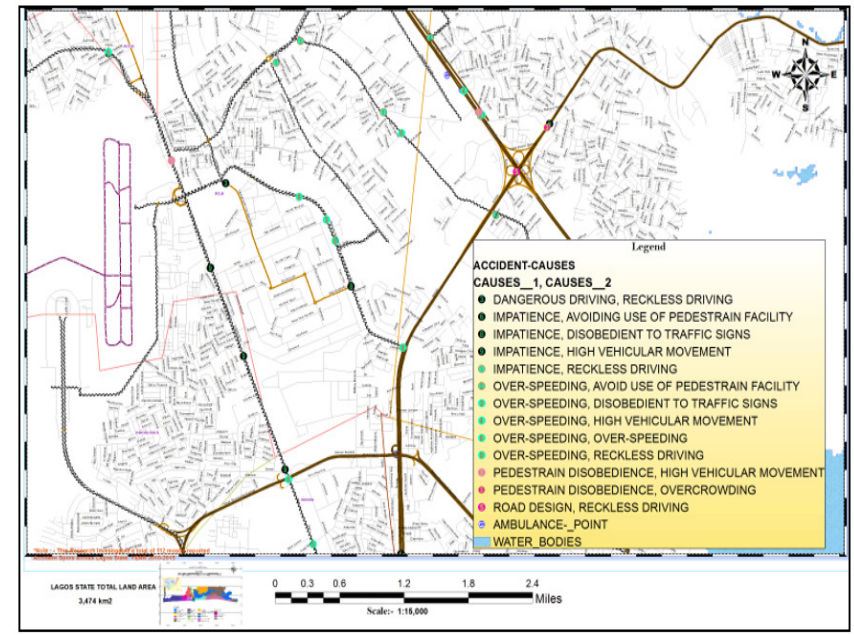

Fig. 2: Major Causes of Road Accidents.

Causes of Accident in the Study Area can be ranked as follows: Drivers Over-Speed (45.5\%), Impatience (34.8\%) and Bad Road Condition (7.14\%). It implies that Drivers often take advantage of some supposedly Good road conditions to over speed not minding an unforeseen obstruction, miscalculations and wrong break applications especially along Lekki-Ajah Expressways, Third-Mainland Bridge and Osborne Road just to mention but a few.

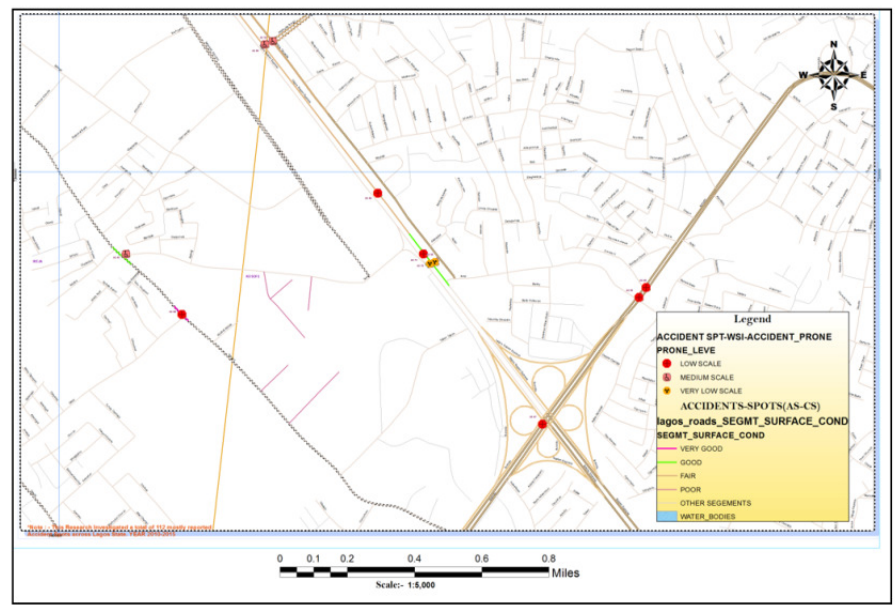

Fig. 3: Accident Spots Vulnerability based on Road Segment Surface Conditions. 
Majority of the Road Segments Surface Conditions are reasonable 21.8\% very good, $34.6 \%$ good, 30.9 fair and 12.8 poor.

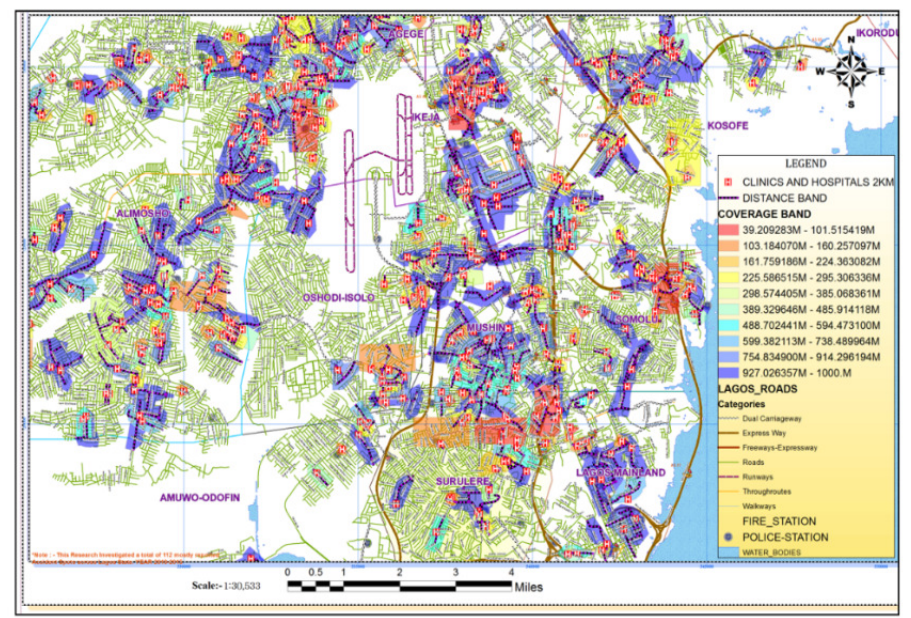

Fig. 4: Hospital Service Areas to Accident Spots within $2 \mathrm{Km}$.

Other generated maps include, Accident Spots located: within certain geographical zone such as Ikorodu LGA, within 50m of Pedestrian Bridge, within $50 \mathrm{~m}$ of Zebra Line; Accident Spots recommended for: ensuring Speed Limit Control treatment, provision of Pedestrian Bridge and ensure usage, Road repair, Traffic Signs-Enforcement Maintenance, and without Pedestrian Aid Facility posing high risk potentials to Pedestrians; Routes for Closest Traffic Enforcement to Accident Spots within $1 \mathrm{Km}$; Service Area Distance of Fire Stations to Accident Spots within 5Km; and Accident Spots along a specific class of roads such as Expressways.

From these mapped generated results, it was concluded that: $3.6 \%$ of the accidents is as a result of pedestrians avoiding the use of pedestrian aid even when they are available e.g. at Obanikoro, Onipanu, Fadeyi (along Ikorodu Road) and former Toll Gate (along Lagos-Ibadan Expressway); whereas $4.5 \%$ of accidents are caused due to lack of Pedestrian Facility along Expressways (e.g. Lagos-Ibadan Expressway (Alausa), Lagos Badagry Expressways Trade Fare).

Ambulance points located across Lagos Roads does not have adequate coverage, the facilities are dilapidated and unmaintained. More lives could be lost due to inefficient mode of rendering rapid first aid treatment to accident victims. Most of the accident occurs at the Metropolitan Areas of the State than outskirts. This can be attributed to high developmental activities, high population coupled with incessant hurriedness, over speeding, impatience, intolerance and reckless driving. Out of the twenty (20) LGAs, results showed that accident spots are more in areas like Ikeja, Eti-osa, Mushin and Amuwo-Odofin LGAs with 25\%, 14\%, $8 \%$ and $7 \%$ respectively.

Using the Weighted Severity Index [WSI] (Table 2), out of the 112 Accident Spots recorded, 9 routes have the highest number of these spots with the following accident prone characteristics (Table 3):

Table 3: Prioritization Scheme for the Selected Roads.

\begin{tabular}{lcccc}
\hline Road/Spot & $\begin{array}{c}\text { Acc_Spot } \\
\text { Code }\end{array}$ & $\begin{array}{c}\text { Individual Cumulative } \\
\text { Wt. }\end{array}$ & $\begin{array}{c}\text { Total Wt. } \\
\text { after Normalizing }\end{array}$ & $\begin{array}{c}\text { Accident Prone } \\
\text { Classification/ } \\
\text { Prioritization Level }\end{array}$ \\
\hline Lekki Ajah & AS 21 & 107 & 76.43 & Very Low \\
Ikorodu Road & AS 63 & 78 & 55.71 & Low \\
Lagos-Ibadan Expressway & & 67 & 47.86 & Medium \\
(Berger Area) & AS 46 & & 60.71 & Very Low \\
Falomo/Ozumba Mbadiwe & AS 20 & 85 & 32.86 & High \\
Abeokuta Expressway (Alimosho & AS 01 & 46 & 56.43 & Low \\
intersection) & & & 47.14 & Medium \\
Lagos-Abeokuta Expressway & AS 44 & 79 & 56.00 & Low \\
$\begin{array}{l}\text { Isolo Road } \\
\text { Third-Mainland Bridge }\end{array}$ & AS 85 & 66 & 40.00 & Medium \\
$\begin{array}{l}\text { Ijaiye Road } \\
\text { (Berger-Roundabout) }\end{array}$ & AS 77 & 77 & 56 & \\
\hline
\end{tabular}


As in Table 3, the Accident Prone Classification/Prioritization Level for all the roads were computed and the percentage distributions of the Weighted Severity Index (WSI) Accident Venerability for them are graphically shown in Fig 5.

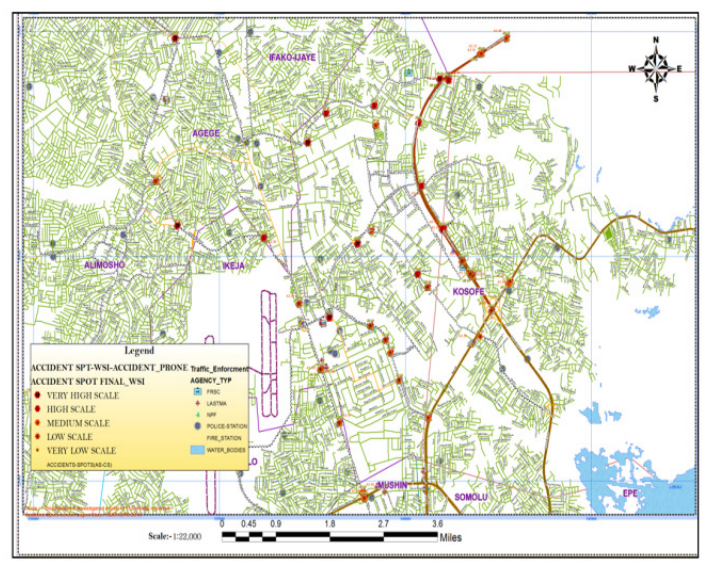

Fig. 5: Weighted Severity Index (WSI) Accident Venerability Map.

Figure 6 shows Cluster Analysis of Accident Spots Concentration. Details of the Spatial Autocorrelation report (Global Moran's I Summary) showed that the $\mathrm{z}$-score $=5.188$ and there is a less than $1 \%$ Moran's index value (i.e. 0.128050). That is, the clustered pattern could be a random chance. The Spatial Autocorrelation report indicates that the accident spots are clustered with concentration in highly built up areas, especially along the expressways, where high human activities and mobility were more pronounced.

Conclusion: In this work, Accident Spots/Black Spots from both primary and secondary data sources were mapped. Accident Spot Severity and Venerability level across the Metropolis based on Weighted Severity Index were carried out using Kernel density methods. Also, Cluster Analysis was carried out to assist in ascertaining the level of distribution of Black Spots. Spatial Autocorrelation report on the distribution of Accident Spots was generated. This research could be a vital tool for stakeholders in the road transport sector.

\section{REFERENCES}

Abiola O., (saved 2011), The Pandemic Rate of Road Accidents In Nigeria. Posted by Abiola Olaifa at $15: 49$

http://www.abiolla.com/2011/06/pandemic-rateof-road-accidents-in.html.

Agbonkhese, O., Yisa, G. L., Agbonkhese, E.G, Akanbi, D.O, Aka, E.O, Mondigha, E.B. (2013). Road Traffic Accidents in Nigeria: Causes and Preventive Measures, Idiroko, Ogun state, Civil and Environment Research, Vol.3, No.13, 2013.

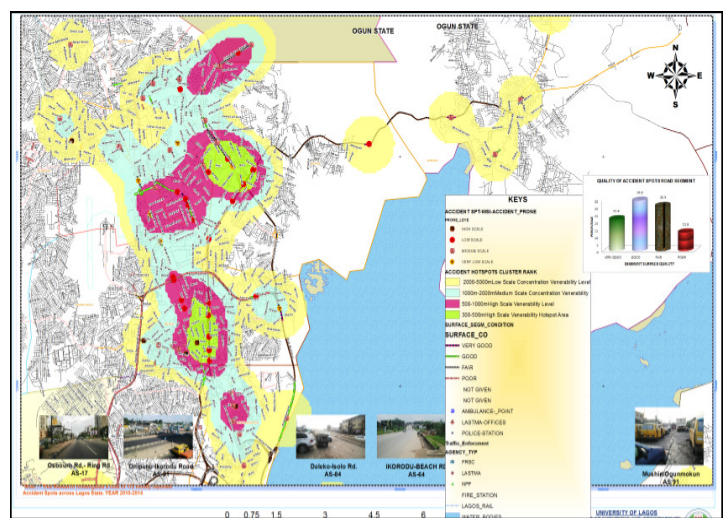

Fig. 6: Graphical Map showing Cluster Analysis of Accident Spots Concentration.

Western Nigeria, Journal of African Research Review. Vol. 4. No.4. Pp. 459-470.

Eze B. (2013). Road Traffic Accidents in Nigeria: A Public Health Problem. In XP Digital ${ }^{\mathrm{TM}}$ (published Sep 8, 2014). Media City, 2nd Floor, 2 Pybus Rd., (Cnr. Pybus \& Rivonia Rd.), Sandton Johannesburg $2146 \quad$ South Africa.http://www.xpdigital.co.za/component/k2/ itemlist/user/2993

Geurts, K. and Wets, G.: (2003). Black Spot Analysis Methods: Literature Review, Flemish Research Center for Traffic Safety, Diepenbeek, Belgium.

Hartigan, J. (1975). Clustering Algorithms. A Wiley Publication in Applied Statistics. John Wiley \& Sons, New York, NY. ISBN 0-471-35645-X

Hartigan, J.A. and Wong, M.A. (1979). Algorithm AS136: A k-means clustering algorithm.

Journal of the Royal Statistical Society. Series C (Applied Statistics), Vol. 28, No. 1 (1979), p. 100-108. Blackwell Publishing for the Royal Statistical Society Stable. http://www.jstor.org/stable/2346830 . Accessed: 18/01/2012 13:10.

Kanellaidis G (1999): Pedestrian safety problems and implementation of counter measures. Journal of International Association of Traffic Safety Sciences (IATSS) 23:2, Japan.

Krug, E.G., Sharma, G.K.; Lozano, R. (2000): The Global Burden of Injuries. American Journal of Public Health. 90(4); 523-526.

Atubi, A.O. (2010b) Road Transport System Management and Traffic in Lagos, South 
Lagos State Ministry of Physical Planning (2014). Administrative Map of Lagos State. Lagos State Secretariat, Alausa, Ikeja.

Landles, J.R. (1979). London's Blackspot program. Transportation Research News, 82, 2-5.

LASTMA, (2013). Lagos and the Crusade for Road Safety http://www.lastma.gov.ng/index.php/18publications/94-lagos-and-the-crusade-for-roadsafety.

Nagarajan, M., and Cefil, M., "Identification of Black Spots \& Accident Analysis on NH-45 Using Remote Sensing \& GIS”, International Journal of Civil Engineering Science, Vol. 1, p.1-7, 2012. National Institute of Statistics and Economic Studies (saved 30/01/2017). Road Accident. Publication date: 13/10/2016 https://www.insee.fr/en/metadonnees/definition/c $\underline{1116})$.

Nkwonta, C. (2013). Causes of Road Traffic Crashes and Prevention. Fleet Management in Nigeria: Road Safety Perspectives. A collection of papers presented at the Federal Road Safety Corps Organised Courses for Safety Managers under The Road Transport Safety Standardization Scheme (RTSSS) Fleet Management in Nigeria: Road Safety Perspectives Edited by Kayode Olagunju (Ph.D.) Federal Road Safety Corps. Published April, 2010. ISBN - 13978 - 978 - 482 - 71 - 2 - 6. http://frsc.gov.ng/fleetmag.pdf

Sarin, S.M. (1998) Road Traffic Safety in Indian Issues and Challenges Ahead, Indian Highways, Vol. 26, No.6., p. 26-38.

Sheriff, M.A. (2009). Traffic Education and Safety in Nigeria. Nitours Journal, vol. II, Kano.
Steenberghen, T., Thomas, I., Dufays, T. and B. Flahaut (2004), Intra-urban location and clustering of road accidents using GIS: a Belgian example. International Journal of Geographical Information Science. (2004) 18, 169-181.

Tabatabaee, S.A. and Johari B. (2012). Providing a Model in Order to Transportation Safety in Accident Black Spots in Suburban Roads from Economical Optimizing Point of View. Vol 4. IJET.

Vyas P., Honnappanavar M.L and Balakrishna H B (2015). Identification of black spots for safe commuting using weighted severity index and GIS. International Journal of Advanced Structures and Geotechnical Engineering (IJASGE 040110). ISSN 2319-5347, Vol. 04, No. 01, January 2015, p. 47-51.

Wang, J. and Wang, X. (2011). An Ontology-Based Traffic Accident Risk Mapping Framework. in Advances in Spatial and Temporal Databases. $12^{\text {th }}$ International Symposium, SSTD 2011 Minneapolis, MN, USA, August 24-26, 2011 Proceedings. Springer Heidelberg Dordrecht London. ISSN 0302-9743 and ISBN 978-3-64222921-3.

Wang J. (2012): A Traffic Accident Risk Mapping Framework, University of Calgary, Alberta. (URL: http://www.geomatics.ucalgary.ca/graduatetheses)

World Health Organisation (WHO) (2013), Road Traffic Injuries.

http://app.imcreator.com/static/B189D9BB44CB 46F8AAD0EEEC4944E941/road-safety-news. 